\title{
Board 126: Early Career Elementary Teachers' Evolving Choices for Incor- porating Engineering into Their Classroom
}

\section{Dr. Jessica E S Swenson, University of Michigan}

Jessica Swenson is a post doctoral research fellow at the University of Michigan. She received her doctorate and masters from Tufts University in mechanical engineering and STEM education. Her current research involves examining different types of homework problems in undergraduate engineering science courses, flexible classrooms, active learning, responsive teaching, and novice elementary engineering teacher development.

\section{Dr. Kristen B Wendell, Tufts University}

Kristen Wendell is Assistant Professor of Mechanical Engineering and Adjunct Assistant Professor of Education at Tufts University. Her research efforts at at the Center for Engineering Education and Outreach focus on supporting discourse and design practices during K-12, teacher education, and college-level engineering learning experiences, and increasing access to engineering in the elementary school experience, especially in under-resourced schools. In 2016 she was a recipient of the U.S. Presidential Early Career Award for Scientists and Engineers (PECASE). https://engineering.tufts.edu/me/people/faculty/kristenbethke-wendell 


\section{Early Career Elementary Teachers' Evolving Choices for Incorporating Engineering into their Classroom (Work-in- Progress)}

Teachers in high-poverty urban and rural districts often face enormous pressure to improve test scores in mathematics and English language arts. Using instructional time for science and engineering is often perceived as a risky move, especially for early career teachers with probationary status. New teachers in high-needs environments do not always feel at liberty to incorporate engineering activities into their classrooms, despite the growing number of teacher preparation programs attempting to equip them to do so (e.g., [1],[2]). Yet, the potential of the Next Generation Science Standards and its inclusion of engineering can only be realized equitably if we know how to support teachers who primarily serve students of color, students from low-income families, and students who need special education or English language support [3]. However, research is limited on whether and how early career teachers in high-needs schools incorporate engineering into their classrooms. In particular, what do they do when conditions are not favorable for engineering instruction, such as when their schools offer no engineering curricula or strongly emphasize reading and math accountability at the expense of other subjects?

In this paper, we present a longitudinal case study of two urban elementary school teachers, Vanessa and Dani, who were committed to engineering instruction during their first two years of classroom teaching. Both teachers were hired for their first positions by schools with high percentages of black or Latino/a students, groups typically underrepresented in STEM. Our study is guided by the research question, how do early career urban elementary school teachers in high-needs schools choose to incorporate engineering into their teaching, and what reasoning and beliefs motivate those choices evolve over time?

\section{Theoretical Framework}

Previous research has shown that elementary teachers who integrate engineering into their established curriculum believe it is important to teach engineering to prepare students for the workforce, help them understand how technology is created, and promote the joy of learning [4], [5]. In this case study, we explore the choices and reasoning of urban educators who see themselves as advocates for high-needs students from immigrant communities [6] and who at the same time develop a deep commitment to including engineering in their classrooms. To frame our exploration, we adopt a critical pedagogy perspective which assumes that teachers' classroom practices may seek to critique societal structures and place their students in "agentic positions to effect change" [7]. We draw upon Freire's vision for for a "liberating critical pedagogy" that enables teachers and students not only to "read the word," or access academic content, but also "read the world," or understand the social, historical, and political context in which they themselves and that academic content are situated [8],[9].

\section{Study Context and Participants}

The data set for this case study comes from a larger research program focused on engineering teacher development through community-based problems [10]. In an elementary teacher 
licensure program at an urban public university, pre-service teachers self-selected to participate in a professional development institute focused on engineering education. After the institute, they were invited to attend monthly meetings of an engineering education professional learning community (PLC) during their first years as in-service teachers. Average attendance at each PLC meeting was five teachers. Over the course of the three years of the PLC program, 17 teachers participated in some way. Of these teachers, approximately $30 \%$ were people of color and $35 \%$ were male, and all had elementary teaching jobs in public schools. The PLC provided access to and advice on engineering curriculum materials as well as funding for classroom supplies. Each meeting began with a round-robin sharing of the ways in which teachers were currently trying to incorporate engineering into their classrooms and the challenges they were facing. This sharing included looking at student work, such as posters, videos, and reports on design prototypes. After celebrating accomplishments and giving input on challenges, the group engaged in an engineering design activity and discussed how they might adapt it to their settings. Some months, the engineering activities were proposed by participants because they wanted to practice a specific design task before doing it with their students (e.g., pop-up cards), and other months, the university-based engineering educators chose activities to expand participants' tools for supporting engineering instruction (e.g., design notebooks, groupwork norms, LEGO robotics).

We focus on two teachers, Vanessa and Dani, two white women who were members of the PLC for two years and taught a number of engineering units in their classrooms during the course of their involvement. They did so without mandate from their school curriculum, colleagues, or administrators. By their second year of involvement in the PLC, the teachers were so interested in engineering teaching that they both also started to take online classes in a graduate certificate program for engineering education.

During the two PLC years, Vanessa was an English language specialist in an urban public K-5 school for newcomer 1st and 2nd grade students who had recently moved to the United States. Her teaching involved both pulling out students for small group lessons on language development as well as partnering with classroom teachers to support her students in the general education classroom. Vanessa did not have a prescribed curriculum to teach mandated by her school. Her main duties were to improve the students' oral and written language abilities and prepare them for the frequently administered ESL tests. Vanessa reported meeting all accountability targets for her students' English language test scores and receiving strong evaluations from her administrator. After her first year of full-time teaching, Vanessa applied for and was awarded grant money from Teaching Tolerance [11] for a proposal to integrate social justice themes with engineering design instruction.

Dani was a 5th grade teacher at an urban public K-8 school serving mainly students from Latino immigrant families. She taught science and math during her first year of work and science and social studies during the second year. Her responsibilities involved teaching the same lessons to three classes per day and addressing state standards of learning in both subjects each year. During her second year of teaching, Dani was invited to join a small committee of teachers working to redesign the science curriculum resources for the city. 


\section{Data Collection and Analysis}

To track the evolution of Vanessa and Dani's choices for teaching engineering, we invited both to be interviewed periodically as they implemented engineering units, which ranged in length from one class session to several months. The first author conducted three interviews with Vanessa and five with Dani, using the same protocol each time. Each interview began with the teacher describing her most recent units, often with pictures of student work and binders of lesson plans. The second part of each interview asked teachers to explain their instructional and pedagogical choices, reflect on why they persisted in teaching engineering, and offer advice for other teachers and teacher educators.

Following interpretive case study methodology [12] we conducted a thematic analysis across all eight interview transcripts to examine longitudinally the teachers' choices and reasoning as engineering teachers. In the first round of analysis, both authors independently reviewed each transcript and tagged any statement in which Vanessa or Dani provided information in one of the following four categories: general goals and reasons for doing engineering, unit-specific learning objectives, instructional design choices, and pedagogical choices. We then collected all tagged statements and sorted them by category and interview date. This collection enabled us to create tables showing all curricular and instructional choices (see Tables 1 and 2). For the second round of analysis, we conducted open coding of the statements within the "general goals and reasons for doing engineering" categories to identify themes of teacher goals and reflections related to elementary engineering teaching. We used constant comparative analysis [13] to refine themes and the statements which belonged to each theme. Finally, we tabulated how many interviews included statements by either teacher supporting each theme. Looking across the teachers and years, we noted which themes were dominant and stable, and which evolved later or were more fragile.

\section{Findings}

Our analysis of the teachers' unit-specific learning objectives, instructional design choices, and pedagogical choices revealed that Vanessa and Dani developed a surprisingly wide-ranging set of design challenge contexts and interdisciplinary connections in just their first two years of teaching. The range of contexts and connections is especially surprising given that neither teacher was positioned by their school as a teacher of engineering. The tables in the appendix show the chronology of engineering instruction that the teachers designed and offered to their students over the course of the two PLC years.

Each of Vanessa's first three activities featured a simple design problem drawn from a story book. The children were challenged to build a small model of a design solution, which they then described orally or in writing to practice language. After a number of these stand-alone storybased activities, Vanessa began conceiving of design challenges on her own. The first focused on systems of a city to help her students better understand a curriculum unit on systems of the human body. The second was a community-based playground design unit that started as a way to practice vocabulary of movement (e.g. run, jump) but evolved into helping a special-needs classroom at her school. Based on the success of this unit, and her encounter with new resources 
for supporting academic talk by English language learners [14], Vanessa developed a longer unit that also included teaching tolerance and advocacy.

Over her first two years of teaching, Vanessa's choices for teaching engineering increased in complexity in a number of ways. While early design challenges were mainly sites for vocabulary practice, the later playground design units required the use of different discursive practices. Vanessa also gradually began to integrate science and math content. Another shift was from offering straightforward construction challenges to posing problems that called upon empathy and advocacy to create solutions for real clients based on interviews and research. Vanessa was always committed to fostering a love of learning and a happy school environment for her students, but she evolved from using construction activities mainly as an aid for student motivation to seeking out challenges of relevance to her students' lives.

Dani first included engineering instruction in her 5th-grade math and science classroom in the spring of her first year of teaching, when she facilitated a wind turbine design challenge involving blade iteration and voltage meter testing and a climate change mitigation unit with three challenges: miniature flood barriers, miniature earthquake-proof structures, and water filtration. In her second year of teaching, Dani developed and enacted four engineering design units: reverse engineering of common appliances, which focused on material properties; Native American house design, emphasizing the diverse ingenuity of different tribal groups; pop-up cards, aimed at geometry concepts of measurement and angles; and water filtration or transport design situated by the novel $A$ Long Walk to Water [15].

Dani's engineering teaching choices also showed increasing complexity along several dimensions, including the number of disciplines in one unit and the degree of agency students had over design testing (the wind turbines and climate change structures were tested according to Dani's procedures, but by Long Walk to Water, the students proposed their own tests and metrics). Dani initially focused on giving students access to the field of engineering itself, but eventually she strove also to empower them to use the disciplines of math, science, history, and literature as tools for solving engineering problems.

Table 1 summarizes the results of our thematic analysis of Vanessa and Dani's responses to questions about why they persist in doing engineering with their students and why they think engineering is important. It shows which themes emerged from both teachers' responses, and which themes appeared for only one teacher. Vanessa, the English language specialist for newcomer 1 st and 2 nd graders, was unique in using engineering as a site for language development and fluency with physical materials. Dani, the 5 th grade math/science/social studies teacher, was unique in using engineering to ground big ideas in other academic disciplines and to widen students' sense of their place in society. Interestingly, however, there were six themes that emerged in both teachers' cases for the importance of elementary school engineering. The most frequently stated reason for doing engineering ( 3 of Dani's interviews, 3 of Vanessa's interviews) was that it creates positive intellectual and emotional engagement for all students. Both teachers also sought to bolster students' identity as engineers and problem solvers and their capacity to collaborate and think creatively and critically. They wanted students to see that engineering could practiced by anyone and used as a force for social good, but they also wanted students to view it as a career within their own each. 
Table 1. Themes representing Vanessa and Dani's general goals and reasons for doing engineering in their elementary classrooms

\begin{tabular}{|c|c|c|}
\hline Dani Only & Both Teachers & Vanessa Only \\
\hline $\begin{array}{l}\text { Using engineering to ground } \\
\text { big ideas in other } \\
\text { academic disciplines (all } \\
5 \text { interviews) }\end{array}$ & $\begin{array}{l}\text { Positive intellectual and emotional engagement } \\
\text { for all students, including English learners } \\
\text { and students from immigrant families ( } 3 \\
\text { interviews for D, } 3 \text { interviews for V) }\end{array}$ & $\begin{array}{l}\text { Situating and spurring oral } \\
\text { and written language } \\
\text { development (all } 3 \\
\text { interviews) }\end{array}$ \\
\hline $\begin{array}{l}\text { Experiencing engineering } \\
\text { problem solving and } \\
\text { iteration ( } 3 \text { interviews) }\end{array}$ & $\begin{array}{l}\text { Students identifying as problem-solving } \\
\text { engineers ( } 3 \text { interviews for D, } 2 \text { interviews } \\
\text { for } V \text { ) }\end{array}$ & $\begin{array}{l}\text { Equal participation in } \\
\text { classroom talk ( } 1 \\
\text { interview) }\end{array}$ \\
\hline $\begin{array}{l}\text { Explicitly learn the } \\
\text { engineering design } \\
\text { process ( } 4 \text { interviews })\end{array}$ & $\begin{array}{l}\text { Experiencing and improving at collaboration ( } \\
\text { interviews for D, } 3 \text { interviews for } \mathrm{V})\end{array}$ & $\begin{array}{l}\text { Greater fluency with } \\
\text { physical materials ( } 1 \\
\text { interview) }\end{array}$ \\
\hline $\begin{array}{l}\text { Broaden perspective as } \\
\text { member of society ( } 1 \\
\text { interview) }\end{array}$ & $\begin{array}{l}\text { Engineering as social good ( } 2 \text { interviews for } \mathrm{D} \text {, } \\
2 \text { interviews for } \mathrm{V} \text { ) } \\
\text { Critical and creative thinking ( } 2 \text { interviews for } \\
\quad \mathrm{D}, 1 \text { interview for } \mathrm{V} \text { ) } \\
\text { Equal access to engineering as career }(2 \\
\text { interviews for } \mathrm{D}, 1 \text { interview for } \mathrm{V})\end{array}$ & \\
\hline
\end{tabular}

\section{Discussion and Conclusions}

In this longitudinal case study of two early career urban teachers who self-selected into a professional learning community focused on elementary engineering, we found that both took broad initiative to offer a range of engineering design challenges with specific multidisciplinary learning objectives. This first finding is noteworthy on its own: it shows the capacity of novice elementary teachers, when supported by a professional learning community, to enact sophisticated engineering instruction even in high-needs classrooms. However, findings from our second round of analysis show that in addition to this instructional competence, each teacher had also developed a multifaceted, social-justice oriented argument for the importance of engineering as an elementary school learning experience. By the end of their second years as teachers, both Vanessa and Dani were applying ideas from critical pedagogy to make elegant, complex cases for incorporating engineering instruction into high-needs elementary schools [16]. And they were supporting their cases with evidence from their own classrooms.

This work has implications for engineering teacher education, as it suggests that early career elementary teachers have interest and capacity for weaving engineering into their work as allies of students in high-needs schools and advocates for liberating pedagogy that enables all students to use the STEM subjects in service of "reading the world" and carving out their place in it. Teacher educators should consider introducing engineering to elementary teachers through community-based projects and support them in developing their own engineering curriculum based in the communities in which they teach. Our findings point to possibilities for future research on the experiences and outcomes of the students in Vanessa and Dani's classrooms and others like them. 


\section{Acknowledgements}

This paper was supported by the National Science Foundation under grant numbers 1623910 and 1253344. We are grateful for the extensive collaboration of teachers Vera Gor and Rae Woodcock, and for the contributions made by Tejaswini Dalvi and Dana Levin to the Community-Based Engineering project. We thank the Tufts University Center for Engineering Education and Outreach for their support.

\section{References}

1. Mangiante, E. S., \& Moore, A. (2016). Attending, analyzing, and responding to student thinking for engineering design. Paper presented at the 2016 National Association for Research in Science Teaching Annual International Conference, Baltimore, MD, 14-17 April.

2. Rose, M. A., Carter, V., Brown, J., \& Shumway, S. (2017). Status of elementary teacher development: Preparing elementary teachers to deliver technology and engineering experiences. Journal of Technology Education, 28(2), 2-18.

3. NGSS Lead States. (2013). Next Generation Science Standards. Washington, D.C.: National Academies Press.

4. Lachapelle, C. P., Hertel, J. D., Shams, M. F., San Antonio, C., \& Cunningham, C. M. (2014). The attitudes of elementary teachers towards elementary engineering (research to practice). American Society for Engineering Education Annual Conference \& Exposition.

5. Yaşar, Ş., Baker, D., Robinson-Kurpius, S., Krause, S., \& Roberts, C. (2006). Development of a survey to assess K-12 teachers' perceptions of engineers and familiarity with teaching design, engineering, and technology. Journal of Engineering Education, 95(3), 205-216.

6. Puig, V. I., \& Recchia, S. L. (2012). Urban advocates for young children with special needs: First-year early childhood teachers enacting social justice. The New Educator, 8(3), 258-277.

7. Ritchie, S. (2012). Incubating and sustaining: How teacher networks enable and support social justice education. Journal of Teacher Education, 63(2), 120-131.

8. Freire, P. (2005). Pedagogy of the oppressed (Ramos, M. B. , Trans.). New York, NY: Continuum. (Original work published 1970)

9. Freire P., Macedo D. (1987). Literacy: Reading the word and the world. Westport, CT: Bergin \& Garvey.

10. Dalvi, T., Wendell, K. B., \& Johnson, J. (2016). Community-based engineering: Experiences from a $2^{\text {nd }}$ grade urban classroom. Young Children, 71(5), 8-15.

11. Southern Poverty Law Center (2019). Teaching Tolerance Educator Grants. https://www.tolerance.org/about/educator-grant-guidelines

12. Merriam, S. B. (1998). Qualitative research and case study applications in education. Jossey-Bass.

13. Glaser, B., \& Strauss, A. (1967). The discovery of grounded theory. London, UK: Weidenfeld and Nicholson.

14. Wisconsin Center for Education Research. (2018). Student moves: Teach the language of complex thinking. Web article from the Doing and Talking Math and Science project.

http://stem4els.wceruw.org/How/student.html 
15. Park, L. S. (2011). A long walk to water. HMH Books for Young Readers.

16. Duncan-Andrade, J. M. R., Morrell, E. (2008). The art of critical pedagogy: Possibilities for moving from theory to practice in urban schools. New York, NY: Peter Lang. 


\section{Appendix}

Appendix Table 1: Vanessa's Engineering Curriculum Choices
\begin{tabular}{|l|l|}
\hline Curriculum Focus and Dates & Specific Learning Objectives \\
\hline Muncha Muncha Muncha, ${ }^{*}$ Oct. 2016 & Use of food-related vocabulary, sequencing of stories \\
\hline 3 Little Pigs, November 2016 & Vocabulary, sequencing of stories, description, teamwork \\
\hline Peter's Chair, February 2017 & Practice or use of vocabulary, describing artifacts, comparing artifacts. \\
\hline City Systems, March 2017 & Function of part in a system, network of systems, writing practice \\
\hline Playground Challenge, May 2017 & $\begin{array}{l}\text { Express vocabulary that had already been learned } \\
\text { Share designs using explanations }\end{array}$ \\
\hline $\begin{array}{l}\text { Teaching Tolerance Playground } \\
\text { Challenge, February-May 2018 }\end{array}$ & $\begin{array}{l}\text { Language objectives including discourse moves and academic language" } \\
\text { Practice particular functions of language and grammar of particular } \\
\text { sentence forms } \\
\text { Listening, speaking, and writing standards } \\
\text { Motivation for kids to raise their hands, talk, and discuss work } \\
\text { Tolerance and advocacy }\end{array}$ \\
\hline
\end{tabular}

*These lessons involve using engineering to solve problems faced by book characters.

\begin{tabular}{|c|c|}
\hline $\begin{array}{l}\text { Curriculum Focus and } \\
\text { Dates }\end{array}$ & Specific Learning Objectives \\
\hline $\begin{array}{l}\text { Wind Turbines } \\
\text { May } 2017 \\
\end{array}$ & $\begin{array}{l}\text { Investigate wind turbine blade shape and relationship to energy production } \\
\text { Science of energy conversion between mechanical and electrical } \\
\text { Redesign }\end{array}$ \\
\hline $\begin{array}{l}\text { Climate Change } \\
\text { Mitigation } \\
\text { June } 2017\end{array}$ & $\begin{array}{l}\text { Create solutions to the climate change problems they've been learning } \\
\text { Research a problem and use graphing to display results } \\
\text { Make decisions about materials }\end{array}$ \\
\hline $\begin{array}{l}\text { Materials \& Product } \\
\text { Design Unit } \\
\text { September \& October } \\
2017\end{array}$ & $\begin{array}{l}\text { Answer the question: How do engineers make products work? } \\
\text { Substances have a unique set of properties that can be detected/tested including shape, } \\
\text { reflectivity, conductivity, solubility, and magnetism } \\
\text { Why a part/product would need a certain property, how engineers choose materials } \\
\text { Use sketches or drawings to show how parts of device are related } \\
\text { Vocabulary words for properties of materials } \\
\text { Relationship between parts of product and the whole }\end{array}$ \\
\hline $\begin{array}{l}\text { Native American House } \\
\text { Design } \\
\text { November } 2017\end{array}$ & $\begin{array}{l}\text { Knowledge about different Native American survival strategies for different climates } \\
\text { Deeper, longer lasting understanding about Native American strategies/adaptations } \\
\text { Contrasting European accounts of Native Americans as ignorant with demonstrating } \\
\text { their great intelligence and resourcefulness to develop survival strategies and } \\
\text { dwellings } \\
\text { Appreciation for Native American diversity and intelligence }\end{array}$ \\
\hline $\begin{array}{l}\text { Geometry Pop-up Cards } \\
\text { April } 2018\end{array}$ & $\begin{array}{l}\text { Classify quadrilaterals and triangles by their angles and sides } \\
\text { Measure and compare angles } \\
\text { Understand how geometry is applied in the real world }\end{array}$ \\
\hline $\begin{array}{l}\text { A Long Walk to Water } \\
\text { June } 2018\end{array}$ & $\begin{array}{l}\text { Awareness of limited water resources } \\
\text { Understand the engineering design process } \\
\text { Multiplication to calculate the cost of producing multiple designs } \\
\text { Empathy, gratitude, broadening their world perspective }\end{array}$ \\
\hline
\end{tabular}

